Primljen / Received: 18.2.2013.

Ispravljen / Corrected: 16.8.2013.

Prihvaćen / Accepted: 15.10.2013.

Dostupno online / Available online: 10.11.2013.

\section{Applying the analytic network process for risk assessment in sustainable ground improvement}

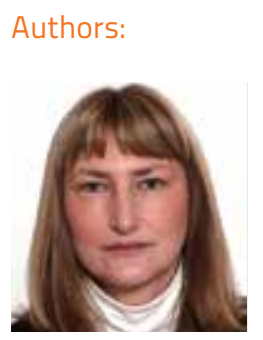

Prof. Anita Cerić, PhD. CE

University of Zagreb

Faculty of Civil Engineering

Department of Construction Management and Economics

anita@grad.hr

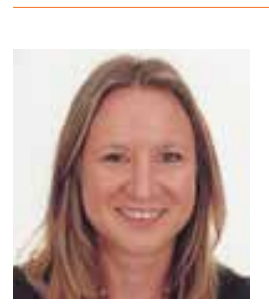

Assist.Prof. Danijela Marčić, PhD. CE

University of Zagreb

Faculty of Civil Engineering

Department for Geotechnical Engineering

djk@grad.hr

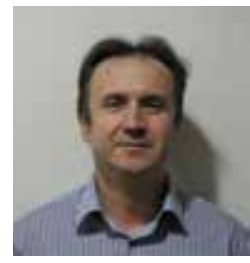

Prof. Meho Saša Kovačević, PhD. CE University of Zagreb

Faculty of Civil Engineering

Department for Geotechnical Engineering msk@grad.hr
Subject review

\section{Anita Cerić, Danijela Marčić, Meho Saša Kovačević}

\section{Applying the analytic network process for risk assessment in sustainable ground improvement}

Constructing foundations for heavy buildings on soft ground can be carried out by ground improvement. Sustainable ground improvement is achieved by adding synthesised binding materials - geopolymers. Natural ground composition in this way is transformed into new material. This paper presents the implementation of the Analytical Network Process (ANP) for assessing risk in sustainable ground improvement. Sensitivity analyses have shown exceptionally stable decision making results.

\footnotetext{
Key words:

Analytic Hierarchy Process (AHP), Analytic Network Process (ANP), sustainable ground improvement, risk assessment, geopolymers
}

Anita Cerić, Danijela Marčić, Meho Saša Kovačevię

Pregledni rad

Primjena analitičkog mrežnog procesa za procjenu rizika u održivom poboljšanju tla

Temeljenje teških građevina u mekom tlu može se riješiti poboljšanjem tla. Održivo poboljšanje tla postiže se miješanjem tla sa sintetiziranim vezivima - geopolimerima. Prirodno tlo se na taj način pretvara u novi materijal. U radu je prikazana primjena analitičkog mrežnog procesa (ANP) za procjenu rizika u održivom poboljšanju tla. Analize osjetljivosti pokazale su izrazitu stabilnost rezultata odlučivanja.

Ključne riječi:

analitički hijerarhijski proces (AHP), analitički mrežni proces (ANP), održivo poboljšanje tla, procjena rizika, geopolimeri

Übersichtsarbeit

Anita Cerić, Danijela Marčić, Meho Saša Kovačević

\section{Anwendung des analytischen Netzwerkprozesses für Risikobewertung in nachhaltiger Bodenverbesserung}

Die Konstruktion von Fundamenten für schwere Bauten auf weichem Grund wird oft durch eine Verbesserung des Bodens ausgeführt. Nachhaltige Bodenverbesserung kann durch die Anwendung von synthetisierten Bindemitteln (Geopolymeren) erzielt werden. Der natürliche Aufbau des Bodens wird dadurch in ein neues Material transformiert. Diese Arbeit beschreibt die Implementation des analytischen Netzwerkprozesses (ANP) für die Risikobewertung in der nachhaltigen Bodenverbesserung. Sensibilitätsanalysen haben ausgesprochen stabile Resultate im Entscheidungsprozess gezeigt.

Schlüsselwörter:

analytischer Hierarchieprozess (AHP), analytischer Netzwerkprozess (ANP), nachhaltige

Bodenverbesserung, Risikobewertung, Geopolymere 


\section{Introduction}

Ground improvement is a technological procedure by which the stiffness and load-bearing capacity of ground is increased. The procedure reduces overall and differential settlements, time required for deformation to appear, and ground permeability. It may increase the ground erosion stability and reduce the danger posed by liquefaction. Growing requirements for foundations that would be capable of supporting heavy infrastructural facilities in extreme conditions, have resulted in rapid development of technologies and ground improvement techniques [1]. Elements of various shapes and configurations occur in ground when mechanical plant is used in order to add binding compounds to the soil [2]. Different types of materials are incorporated into the ground, which may to a lesser or greater extent pollute the surrounding environment, and negatively impact ground water sources [3].

Large quantities of natural raw materials and fossil fuels are consumed during production of standard binding materials, cement and lime. Due to chemism, i.e. $\mathrm{CaCO}_{3}$ decarbonisation, huge quantities of $\mathrm{CO}_{2}$ are released into the atmosphere. The chemism and properties of binding materials result, during hydration, in the creation of synthetic binding compounds, which are known as geopolymers [4]. The introduction of synthetic binding compounds can reduce the percentage of cement and lime used in ground improvement procedures, and this by utilising waste material from industrial processes such as slag and fly ash $[5,6]$. Weight proportions of cement and limestone in the ground improvement procedure amounts to $2-5 \%$. A reduction in the consumption of cement and lime correlates to a reduction in the consumption of natural raw materials and fossil fuels, which consequently results in lower $\mathrm{CO}_{2}$ emissions. For instance, at least $20 \mathrm{~kg}$ of cement and a consumption of $30 \mathrm{~kg}$ of natural raw materials, including $97 \mathrm{MJ}$ of fossil fuels, is needed to improve a ton of the ground mass material. Therefore, $18 \mathrm{~kg}$ of $\mathrm{CO}_{2}$ is emitted into the atmosphere [7].

After selection of an appropriate binding compound, ground improvement level, an appropriate sustainable ground improvement technology, and methods for verification of improvement results, we come to the point when it is possible to manage risks and quantify the success of undertaken works [8]. Risk management in sustainable ground improvement has been previously analysed in [9-13].

\section{Risk on sustainable ground improvement projects}

A large number of potential risks, i.e. events with undesirable results that may affect the project's success, can be identified on any sustainable ground improvement project. In fact, any activity undertaken during implementation of a project is a potential source of problem. It would be quasi-impossible to draw up a general list of all risks appearing on such projects, regardless of the project's size, type and content, i.e. particular features of the project. The aim of identification is to form a list of key risks for each particular sustainable ground improvement project. A proper attention should be paid to risks and associated consequences in all key decision-making areas throughout the life of the project, and risk abatement activities should be aided by all parties involved in the decision-making process.

Throughout the project life cycle, risk assessment and preparatory works are carried out for each identified risk, depending on risk acceptability and adequate risk response [14]. An action undertaken in reply to a risk may cause additional risks, whereby such risks should be identified, analysed and depending on risk acceptability a risk response should be devised. This risk management process becomes cyclic in nature [15].

Risk assessment in construction projects has been previously studied in [16-20]. The risk assessment is carried out by determining risk exposure. The risk exposure is a multiple of risk probability and risk impact [21]. Risk probability is a dimensionless quantity. Risks may impact time, cost, quality, or the environment. However, all forms of impact can be expressed in monetary terms [22]. This means that risk exposure possesses a monetary aspect that can be incorporated into calculations. Consequently, the risk exposure for a particular risk may be attributed any value and is calculated independently of other risks in the project. The absolute value of risk exposure for a particular risk, viewed independently, has almost no practical value. It is therefore important to determine to what extent the risk exposure for a particular risk is greater or smaller than the risk exposure of other risks. A risk priority list can be drawn up by determining risk exposure for all identified risks, and by bringing them into a mutual relationship [23].

Appropriate resources are utilised for the response to planned risk depending on the position of the risk on the risk priority list, i.e. on the relative value of exposure to such risk with respect to other risks. An assessment is made of each risk's acceptability, i.e. appropriate risk management procedures are defined. The relationship between the risk acceptability and risk exposure is derived from the policies established by the risk management team. Such a relationship depends on the type, character and complexity of the project, including previous experience in the realization of similar projects [24].

The topic of environmental risk assessment on construction projects has been studied by many authors [25-29]. The risk priority list resulting from risk assessment can be determined using a quantitative approach, a qualitative approach, or a combination of the two. The quantitative approach in forming a priority list implies that the risk probability and risk impact can be calculated explicitly using a known quantitative risk analysis method. This requires utilisation of an appropriate database in forming a distribution of values, i.e. for allowing calculation of the impact on time, cost, quality and environment. A qualitative approach in forming a priority list is used when there is no appropriate database containing data from previous projects, which would otherwise provide a function for allocating values and determining risk probability. All necessary indicators for direct calculation of consequences, i.e. impacts the risky event would have on time, cost, quality and environment, are also unavailable. The most common case in real life is a combination of the quantitative and qualitative approach. For some risks, the information about possibilities for assessing probability and impact is available. 
For some other risks, this is not possible. If risk probability can be calculated for all risks, a normalisation procedure, i.e. the socalled quantitative approach, should be applied. If at least one risk cannot be calculated, the risks that can be calculated should be normalised in the first place. Furthermore, a qualitative approach should be applied to the probability relationship for such risks and for the types of risks for which probability can not be calculated. The same procedure should be used for the impact of risk on the time, cost, quality and environment.

\section{Analytic Network Process (ANP)}

The Analytic Network Process was used in this paper for risk assessment in sustainable ground improvement. It belongs to the group of multi-criteria decision making methods. The ANP is a generalisation of the Analytical Hierarchical Process (AHP) allowing decision makers to reduce a complex problem to a nonlinear network form, which in itself contains a linear hierarchical form [30-34]. The application of ANP in environmental modelling and construction projects has been previously presented in [3539].

The hierarchical structure contained in AHP is reduced to a multidimensional problem on at least three levels: goal, criteria, and alternatives. Criteria may also have sub-criteria. This is a linear "top-to-down" structure where all the elements at particular levels are independent of one another, whereas elements at higher levels affect the importance of elements at lower levels. The process begins by determining relative importance of particular alternatives with respect to criteria or sub-criteria. Then, the effects the criteria have on the goal are compared. Finally, the results of the two analyses are synthesised in order to calculate the relative significance of the alternative with respect to achievement of the goal.

The network structure contained in the ANP reduces the multidimensional problem to clusters and elements, i.e. nodes within clusters. This non-linear "feedback" structure permits interaction and dependence between elements of one cluster (inner dependence), and dependence between elements of another cluster (outer dependence). Hierarchy is a special network case providing dependence only amongst the elements of various clusters with this dependence being unidirectional, i.e. running from higher-level elements to lower-level elements.

The ANP is an upgrade of the AHP because it provides a comparison of criteria influences with respect to alternatives, and a comparison between individual alternatives on account of the control criterion that may be the goal in the hierarchical structure. The interdependence of network elements allows better modelling of complex problems since the majority of real-life problems are non-linear, while the feedback link provides a precise determination of the priority of elements and a higher quality decision making. The functional interaction between criteria and alternatives in models provides better stability of analysis results. This makes the ANP especially suitable for risk assessment.

In risk analysis, the outer dependence can be presented using as an example the risk impact determination for identified risks Risk1 and Risk2. Criteria for determining the impact are a prolongation/ delay in carrying out the project (time), and an unfavourable risk impact on the surroundings (environment). Risk1 exerts a small influence on the environment but extends considerably the time needed to carry out the project, whereas Risk2 is of no great significance for the duration of the project, but it exerts a much greater influence on the environment when compared to Risk1. Taking into account that this is a project of significance for a wider social community, the environment criterion has a greater priority than the time criterion. In the hierarchical structure (AHP) the Risk 1 acquires a greater priority as it is less harmful to environment. In the feedback network structure (ANP), the impact the criteria have on alternatives can be compared. When comparing criteria for Risk1, the environment criterion may be assessed as being significantly more dominant and more important than the time criterion. In this type of network structure, Risk2 can acquire a greater priority than Risk1. This conforms to the priorities that are established in real life since it is reasonable to conclude that, when confronting two risks whose influence on the environment is satisfactory, a greater priority is given to the risk that significantly prolongs the time needed to carry out the project.

To illustrate the inner dependence, at least 3 alternatives or the identification of 3 risks are necessary: Risk1, Risk2, and Risk3. The starting point comes from the logical statement that risks are not mutually dependent in relation to risk impact. An assertion is made as to what extent the Risk2 has a greater risk impact than the Risk3 with respect to the Risk1. For instance, an assertion is made concerning ground improvement as to how much greater is the risk impact of an inappropriately selected ground improvement technology, than the risk of works realized in an unsatisfactory manner, with respect to the risk of inadequate exploratory works. It is clear that inadequate implementation of exploratory works exerts a much greater influence on the choice of ground improvement technology than the realization of works. The use of the ANP for risk assessment on construction projects has been previously studied in [40-45].

\section{Application of the ANP method for risk assessment in sustainable ground improvement}

The use of ANP is illustrated on the example of the oncoming construction of an international furniture retail centre at the eastern periphery of Zagreb, capital of Croatia. The size of the plot planned for construction is approx. $80,000 \mathrm{~m}^{2}$, while the facility itself will occupy an area of approx. $25,000 \mathrm{~m}^{2}$. On this project, the foundations will consist of footings and foundation slabs of various sizes. According to design requirements, the total settlement and differential settlement should not exceed $3,0-3,5 \mathrm{~cm}$, and 0,5-1,0 cm, respectively. It was revealed during geotechnical investigations that $14 \mathrm{~m}$ of the top layer consist of a very compressed clay and organic soil, whereas further down the compacted sand and gravel are encountered. The foundation soil is characterized by low stiffness and poor load-bearing characteristics, and so the soil must be improved in order to reduce 
total and differential settlements, and increase the load-bearing properties of soil. As the facility will be constructed along the Sava River, ground improvement activities represent an ecological problem due to possible pollution hazard. The identified key risks in sustainable ground improvement which represent alternatives in the ANP model are:

- Inadequate site investigations

- Selection of inappropriate ground improvement technique

- Poor detailed design for elements of chosen solution

- Unsatisfactory suppliers work performance

- Low-quality monitoring of ground improvement work

Geotechnical investigations serve as the basis for selecting a foundation method and designing the foundation structure. Abandoning the project prior to realization is the most extreme case when geotechnical investigations show that it is better to abandon the project altogether, rather than to try to define foundations for a structure. An alternative to abandoning the project would be to relocate it to an another location characterized by an acceptable stiffness and bearing capacity, or to replace the existing ground with new, stiffer and more stable ground suitable for the future structure. Replacing the ground is technically and economically possible down to relatively small depths. In situations where weak soil is found in greater depths, it becomes necessary to design the foundation structure taking into account the small stiffness and load bearing capacity of the soil, or to improve the ground.

Today, there are may ground improvement technologies such as: deep vibration compaction, deep mixing, jet grouting, vibro replacement, and so on. The choice of a ground improvement technology depends on the quality and type of investigation works. The most frequent case is that, once the ground improvement technology is selected, it becomes necessary to undertake additional investigation works for design requirements. The choice of technology for ground improvement directs the methodology for the design, implementation and quality control when improving ground.

The level of foundation construction design depends on the choice of technology that will be used for ground improvement. For a large number of improvement technologies that are applied in the current civil engineering practice, there are actually no standard for defining design procedures that would reliably determine the level to which physical and mechanical characteristics of the ground are improved following the improvement activities. That is why a test section is set up at the design phase in order to test results of improvement activities and, consequently, to verify the design solution. An alternative is to change the ground improvement technology and conduct additional investigation works.

The actual realization of works is regarded as a critical phase in the implementation of any civil engineering project. The success of ground improvement prior to undertaking works is greatly dependant on geotechnical investigation works, the choice of technology for ground improvement and the project level, whereas after the works there is also the quality control of the undertaken works.
Following the ground improvement works, a great attention is paid to the quality control of the achieved improvements. The complex state of stresses and interaction between incorporated materials and the surrounding soil prevents the calculation of stiffness and strength components of the composition using local testing only. In order to determine the level of ground improvement it becomes necessary to undertake testing on a larger volume of improved soil and to define its average newly formed physical and mechanical characteristics. Depending on the quality control results, the previously stated ground improvement phases are verified and updated.

It is evident from the above discussion that the mutual influence of all identified risks becomes very appropriate for the ANP method. The Superdecisions software package (version 2.0.8) was used in the ANP model development. The ANP model consists of a main network and two subnets. Considering that risk exposure is defined as a multiple of the risk probability and risk impact, the main network represents the risk exposure whereas the subnet represents the risk probability and risk impact. The Risk Probability subnet contains only the Probability criteria and five alternatives or key risks that are analysed. The Risk Impact subnet contains five criteria: time, costs, quality and environment, as well as five alternatives or key risks that are analysed. After the modelling, alternative weight values are obtained for each subnet. In order to acquire the final result from the ANP model, i.e. the risk exposure for each alternative, every alternative is multiplied by its weight value in both subnets. The normalisation of risk exposure values for all alternatives provides a risk priority list.

The network structure of the ANP model depends on modelling the dependence between the clusters and elements or criteria and alternatives. Three models illustrating advantages of the ANP model for risk assessment in sustainable improvement activities are presented below. Comparisons presented in this study are based on the Saaty scale [46]. Consistency coefficients for each compared matrix, at all levels, determined using characteristic values of a comparable matrix, including the global consistency coefficients, are significantly lower than 0.10 . In that way, consistent valuations are made at all hierarchical levels. All comparisons were made by the authors of the paper on the basis of personal experience using high criteria methods when making decisions in geotechnical engineering $[3,8,15,23,46$ i 47$]$.

\subsection{AHP model}

If there are no feedback links between elements from various clusters, and if the dependence is directed in one direction only, i.e. from a higher-level element to a lower-level element, or from criteria to alternatives, the ANP model is transformed into its simplified AHP model. The modelling comprises ten comparisons of the significance of five elements from the Alternatives cluster with respect to one element from the Probability cluster, six comparisons of the significance of four elements from the Criteria cluster with respect to one element from the Impact cluster, and forty comparisons of the significance of five elements from the Alternatives cluster with respect to four elements from the Criteria cluster. 


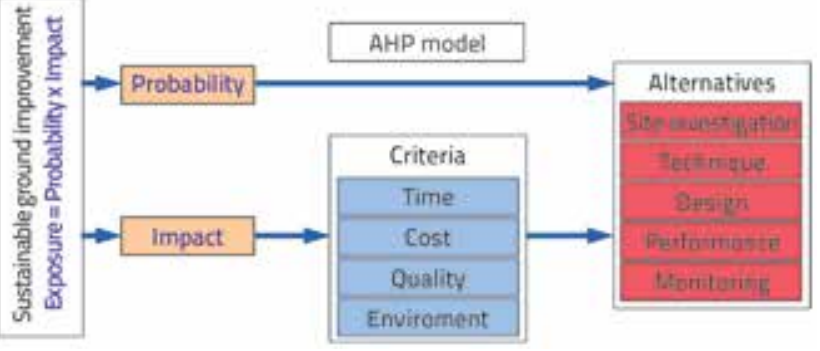

Figure 1. The AHP model network structure

Table 1 shows a comparative matrix of relative significance for elements from the Alternatives cluster with respect to the element from Probability cluster, providing an alternative significance with respect to Probability, i.e. the relevant value of occurrence for each identified key risk. In conclusion, Site Investigation is 3,1 times more probable than Monitoring, whereas Designis 1.5 times less probable than Performance. Evidently, the Site Investigation risk has the highest probability, whereas the Monitoring risk has the lowest probability.

Table 2 shows a comparative matrix of relative significance of elements from the Criteria cluster with respect to the element from the Impact cluster, and the acquired criteria significance with respect to Impact. In conclusion, the Time is 3,5 more important than the Quality, whereas the Cost is 2.5 times less important than the Environment. Evidently, the highest significance is given to the Environment criterion, whereas the Quality criterion has the lowest significance.
For the purpose of illustrating a comparison of alternatives and criteria, Table 3 shows a comparative matrix of relative significance for elements from the Alternatives cluster with respect to the Environmentelement from the Criteriacluster, and the significance of alternatives with respect to the Environment criterion was obtained. In conclusion, the Site investigation is 1,5 times more important than the Monitoring, whereas the Design is 2 times less important than the Performance risk. Evidently, the highest significance is given to the Technique risk, whereas the lowest significance is given to the Monitoring risk.

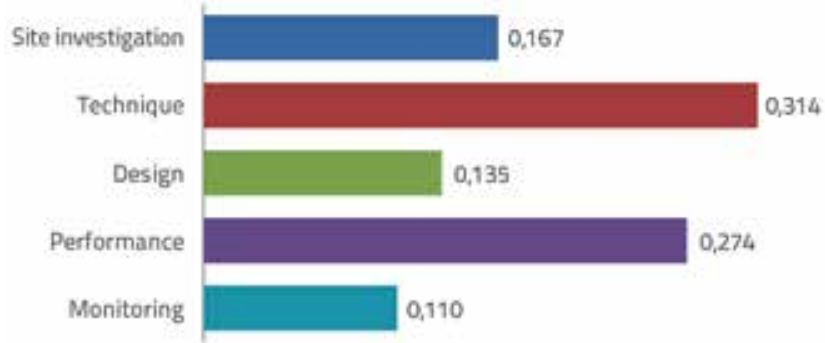

Figure 2. Risk Impact for AHP model

The synthesis of analyses conducted for the Risk Impact is shown in Figure 2. Evidently, the greatest impact comes from the Technique risk, whereas the least comes from the Monitoring risk. Here too, the weakness of the hierarchical model is evident. It is obvious that the risk of choosing an inappropriate technology or Technology risk will receive the greatest significance with respect to the Impact, since

Table 1. A comparison of alternatives with respect to Probability

\begin{tabular}{|c|c|c|c|c|c|c|}
\hline Risk & Site Investigation & Technique & Design & Performance & Monitoring & Priority vector \\
\hline Site investigation & $1 / 1$ & $1,5 / 1$ & $2,5 / 1$ & $1 / 1$ & $3 / 1$ & 0,301 \\
\hline Technique & $1 / 1,5$ & $1 / 1$ & $2 / 1$ & $1,5 / 1$ & $2,5 / 1$ & 0,255 \\
\hline Design & $1 / 2,5$ & $1 / 2$ & $1 / 1$ & $1 / 1,5$ & $1,5 / 1$ & 0,133 \\
\hline Performance & $1 / 1$ & $1 / 1,5$ & $1,5 / 1$ & $1 / 1$ & $2 / 1$ & 0,213 \\
\hline Monitoring & $1 / 3$ & $1 / 2,5$ & $1 / 1,5$ & $1 / 2$ & $1 / 1$ & 0,098 \\
\hline
\end{tabular}

Table 2. A comparison of criteria with respect to Impact

\begin{tabular}{|c|c|c|c|c|c|}
\hline Criteria & Time & Cost & Quality & Environment & Priority vector \\
\hline Time & $1 / 1$ & $2 / 1$ & $3,5 / 1$ & $1 / 1,5$ & 0,309 \\
\hline Cost & $1 / 2$ & $1 / 1$ & $2 / 1$ & $1 / 2,5$ & 0,167 \\
\hline Quality & $1 / 3,5$ & $1 / 2$ & $1 / 1$ & $1 / 5$ & 0,086 \\
\hline Environment & $1,5 / 1$ & $2,5 / 1$ & $5 / 1$ & $1 / 1$ & 0,438 \\
\hline
\end{tabular}

Table 3. A comparison of alternatives with respect to the Environment criterion

\begin{tabular}{|c|c|c|c|c|c|c|}
\hline Risk & Site Investigation & Technique & Design & Performance & Monitoring & Priority vector \\
\hline Site investigation & $1 / 1$ & $1 / 4$ & $1 / 1,5$ & $1 / 2$ & $1,5 / 1$ & 0,109 \\
\hline Technique & $4 / 1$ & $1 / 1$ & $3 / 1$ & $1,5 / 1$ & $6 / 1$ & 0,419 \\
\hline Design & $1 / 2,5$ & $1 / 3$ & $1 / 1$ & $1 / 2$ & $2 / 1$ & 0,143 \\
\hline Performance & $1 / 2$ & $1 / 1,5$ & $2 / 1$ & $1 / 1$ & $3,5 / 1$ & 0,258 \\
\hline Monitoring & $1 / 3$ & $1 / 6$ & $1 / 2$ & $1 / 3,5$ & $1 / 1$ & 0,071 \\
\hline
\end{tabular}


it has the greatest significance with respect to the Environment criterion (Table 3), while the Environment criterion has the largest significance for the Risk Impact (Table 2).

Figure 3 shows a sensitivity analysis where impact by the Environment criterion on risk impact is varied. The analysis shows that the Performance risk acquires a greater importance than the Technique risk only after the significance of the Environment criterion is reduced from $42 \%$ to $26 \%$.

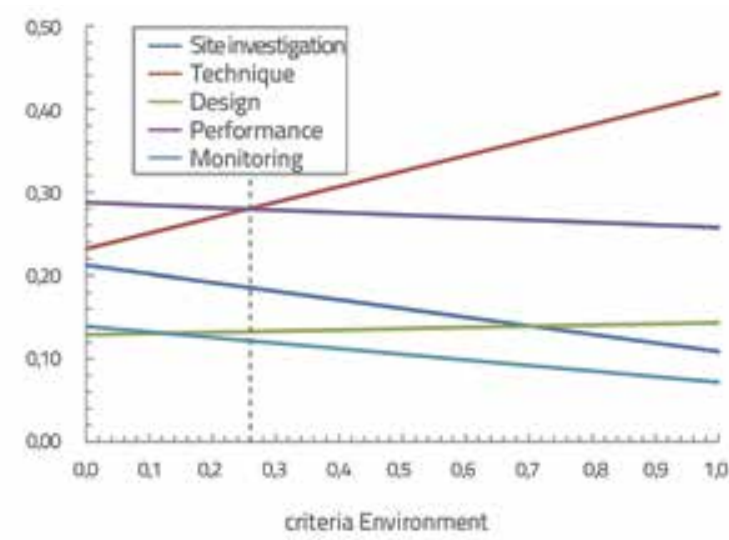

Figure 3. Sensitivity analysis of changes to Environment criterion with respect to Risk Impact

Figure 4 shows the Risk exposure as a normalized multiple of priority vector of Risk Probability shown in Table 1, and Risk Impact obtained by AHP model shown in Figure 5. The AHP model results show that most of the resources should be planned for use with risk management of Technique $(36,7$ $\%)$, followed by Performance $(27,0 \%)$, Site Investigation $(23,1)$, Design (8,2 \%) and, finally, Monitoring (5,0\%).

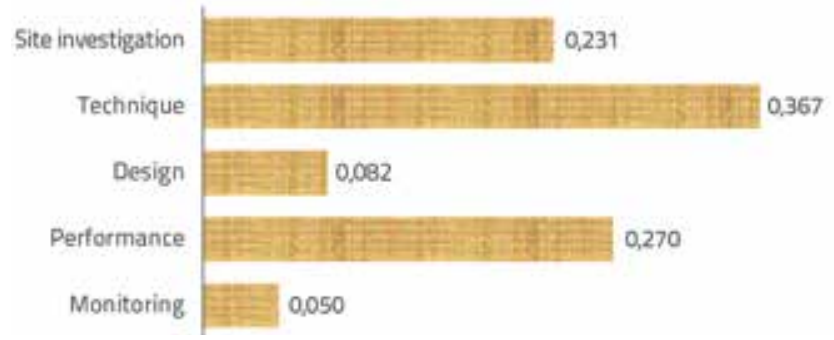

Figure 4. Risk Exposure for the AHP model

\subsection{ANP model 1 with outer dependence}

In order to makethedecision-making process more reliable, and to avoid earlier described inadequacies of the hierarchical model, a feedback link is to beestablished, i.e. the dependence of theelements from the Criteria cluster with respect to the elements from the Alternative cluster in the Impact subnet. The modelling is supplemented with 30 comparisons of significance for 4 elements from the Criteria cluster with respect to 5 elements from the Alternatives cluster (Figure 5).

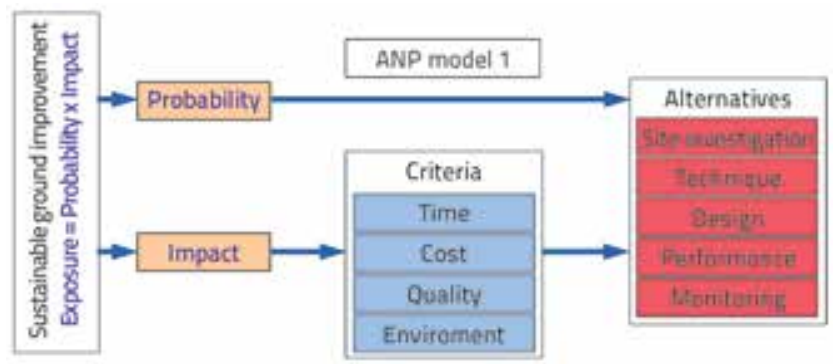

Figure 5. The ANP model 1 with outer dependence structure

The comparison of criteria and alternatives is illustrated in Table 4 which shows a comparative matrix of relative significance for elements from the Criteria cluster and the Technique element from the Alternatives cluster, including the obtained significance of the criteria for the Technique alternative. This illustration was chosen because the Technique risk in the AHP model has the greatest risk impact. In conclusion, the Cost is 1,5 times more important than the Quality criterion, whereas Time is 2,5 times less important than Environment. Evidently, the Environment criterion has the highest significance and the Time criterion possesses the lowest significance.

The synthesis of the Risk Impact analysis is shown in Figure 6. It is now evident that a change has occurred at the top of the risk priority list thanks to the feedback link. The greatest impact is provided by the Performance risk, with the least impact provided by the Design risk. Changes have occurred because the Time criterion has the least significance compared to the Technique alternative, i.e. the selection of an inappropriate technology has the least impact on extending the deadline for the works.

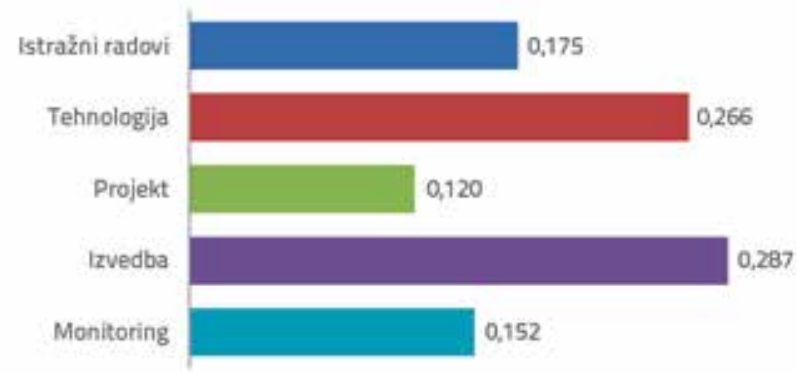

Figure 6. Risk Impact for ANP model 1 with outer dependence

Table 4. A comparison of criteria with respect to Technique alternative

\begin{tabular}{|c|c|c|c|c|c|}
\hline Criteria & Time & Cost & Quality & Environment & Priority vector \\
\hline Time & $1 / 1$ & $1 / 2$ & $1 / 1,5$ & $1 / 2,5$ & 0,144 \\
\hline Cost & $2 / 1$ & $1 / 1$ & $1,5 / 1$ & $1 / 1$ & 0,312 \\
\hline Quality & $1 / 3,5$ & $1 / 1,5$ & $1 / 1$ & $1 / 1,5$ & 0,214 \\
\hline Environment & $1,5 / 1$ & $1 / 1$ & $1,5 / 1$ & $1 / 1$ & 0,330 \\
\hline
\end{tabular}


The sensitivity analysis in which the impact of the Environment criterion on the Technique risk is varied is shown in Figure 7. The analysis shows that the Technique risk would maintain a greater impact than the Performance risk, as witnessed in the AHP analysis, only if the significance of Environment is increased from $34 \%$ to $76 \%$.

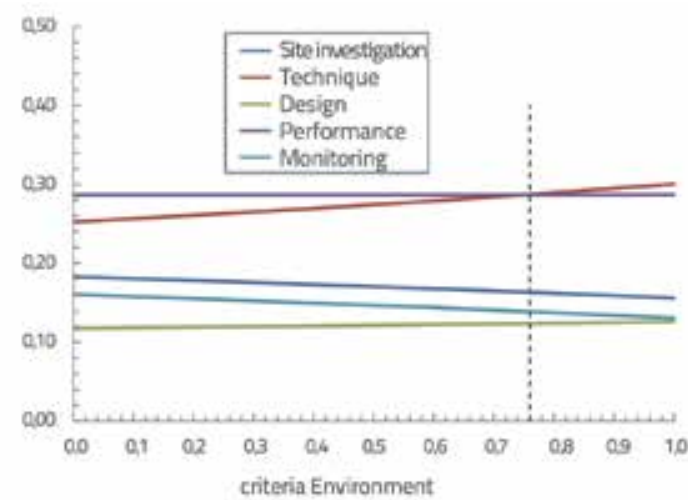

Figure 7. Sensitivity analysis of changes to Environment criterion with respect to Technique risk

Figure 8 shows the Risk exposure as a multiple of the normalized priority vector of Risk Probability shown in Table 1, and Risk Impact obtained by the ANP model 1 shown in Figure 6. Even though a change has occurred in Impact for all risks, the results of the ANP model with outer dependence show that no changes in order have occurred on the risk ranking list since the Technique risk has a greater probability than the Performance risk. Most resources should be planned for managing risks such as Technique (31,9\%), followed by Performance $(28,8 \%$ ), Site investigation $(24,7)$, Design $(7,5 \%)$, and Monitoring $(7,1 \%)$.

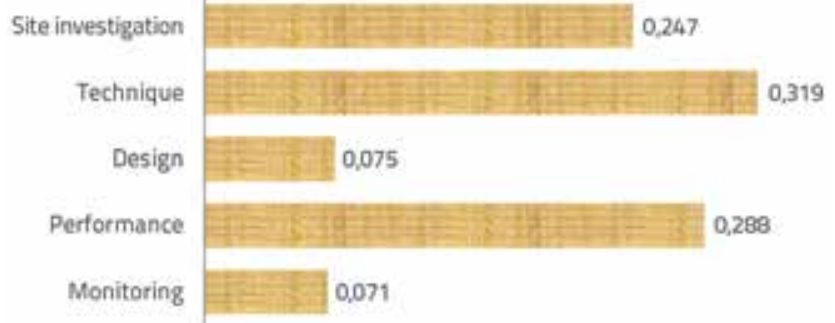

Figure 8. Risk Exposure for the ANP model 1 with outer dependence

\subsection{ANP model 2 with outer dependence and inner dependence}

The best and most reliable decision making process is achieved by adding internal dependences between the elements from the Alternatives cluster to the Impact subnet. The modelling is supplemented with 30 comparisons of significance for 5 elements from the Alternatives cluster with respect to each of them (Figure 9).

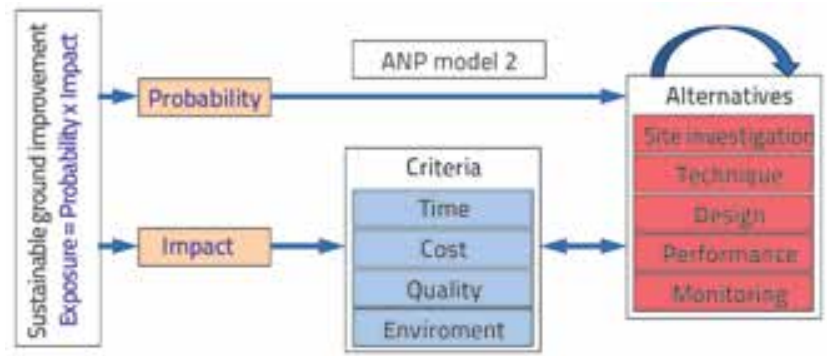

Figure 9. ANP model 1 with outer dependence and inner dependence structure

For the purpose of illustrating the comparison of each of the alternatives, Table 5 shows a comparative matrix of relative

Table 5. A comparison of alternatives with respect to the Peformance alternative

\begin{tabular}{|c|c|c|c|c|c|}
\hline Risk & Site Investigation & Technique & Design & Monitoring & Priority vector \\
\hline Site investigation & $1 / 1$ & $4 / 1$ & $4 / 1$ & $2 / 1$ & 0,500 \\
\hline Technique & $1 / 4$ & $1 / 1$ & $1 / 1$ & $1 / 2$ & 0,125 \\
\hline Design & $1 / 4$ & $1 / 1$ & $1 / 1$ & $1 / 2$ & 0,125 \\
\hline Monitoring & $1 / 2$ & $2 / 1$ & $2 / 1$ & $1 / 1$ & 0,250 \\
\hline
\end{tabular}

Table 6. Unweighted supermatrix with all comparisons

\begin{tabular}{|c|c|c|c|c|c|c|c|c|c|c|}
\hline & $\begin{array}{c}\text { Site } \\
\text { Investigation }\end{array}$ & Technique & Design & $\begin{array}{l}\text { Perfor- } \\
\text { mance }\end{array}$ & Monitoring & Time & Cost & Quality & Environment & Goal \\
\hline $\begin{array}{c}\text { Site } \\
\text { investigation }\end{array}$ & 0,000 & 0,119 & 0,140 & 0,500 & 0,226 & 0,210 & 0,300 & 0,050 & 0,109 & 0,000 \\
\hline Technique & 0,300 & 0,000 & 0,380 & 0,125 & 0,207 & 0,180 & 0,370 & 0,150 & 0,419 & 0,000 \\
\hline Design & 0,200 & 0,059 & 0,000 & 0,125 & 0,117 & 0,140 & 0,150 & 0,050 & 0,143 & 0,000 \\
\hline Performance & 0,400 & 0,584 & 0,290 & 0,000 & 0,450 & 0,360 & 0,070 & 0,450 & 0,257 & 0,000 \\
\hline Monitoring & 0,100 & 0,238 & 0,190 & 0,250 & 0,000 & 0,110 & 0,110 & 0,300 & 0,072 & 0,000 \\
\hline Time & 0,330 & 0,144 & 0,460 & 0,400 & 0,190 & 0,000 & 0,000 & 0,000 & 0,000 & 0,303 \\
\hline Cost & 0,500 & 0,312 & 0,310 & 0,080 & 0,250 & 0,000 & 0,000 & 0,000 & 0,000 & 0,172 \\
\hline Quality & 0,060 & 0,214 & 0,080 & 0,360 & 0,500 & 0,000 & 0,000 & 0,000 & 0,000 & 0,091 \\
\hline Environment & 0,110 & 0,330 & 0,150 & 0,160 & 0,060 & 0,000 & 0,000 & 0,000 & 0,000 & 0,434 \\
\hline Goal & 0,000 & 0,000 & 0,000 & 0,000 & 0,000 & 0,000 & 0,000 & 0,000 & 0,000 & 0,000 \\
\hline
\end{tabular}


significance for elements from the Alternatives cluster with respect to the Performance element, and the obtained significance of alternatives with respect to the Performance alternative. This illustration was chosen since the Performance risk had the greatest risk impact in the ANP model 1. In conclusion, the Site investigation has a two times greater significance than the Monitoring, while the Technique has the same significance as the Design. Evidently, the greatest significance is attributed to the Site investigation alternative, whereas the smallest significance is attributed to the Design and Technique alternatives.

Table 6 shows the unweighted supermatrix which contains the weights or priorities obtained by comparing elements in pairs in accordance with the dependences amongst elements for all shown models.

The synthesis of the Risk Impact analysis is shown in Figure 10. Evidently, the impact of the Performance risk has increased even further with respect to the Technique risk. The greatest impact is attributed to the Performance risk, while now the Design risk has the smallest impact.

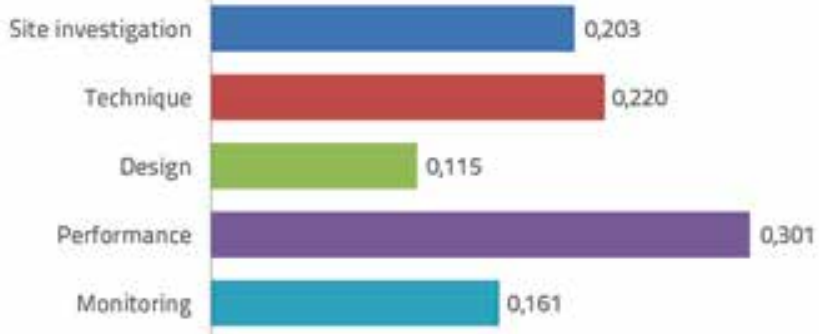

Figure 10. Risk Impact for the ANP model 2 with outer and inner dependence

The sensitivity analysis containing a variation in the impact of the Technique risk on the Performance risk is shown in Figure 11. The analysis shows that the Technique risk has a greater impact than the Performance risk, as in the AHP analysis, only when the significance of Technique is increased from $22 \%$ to $78 \%$.

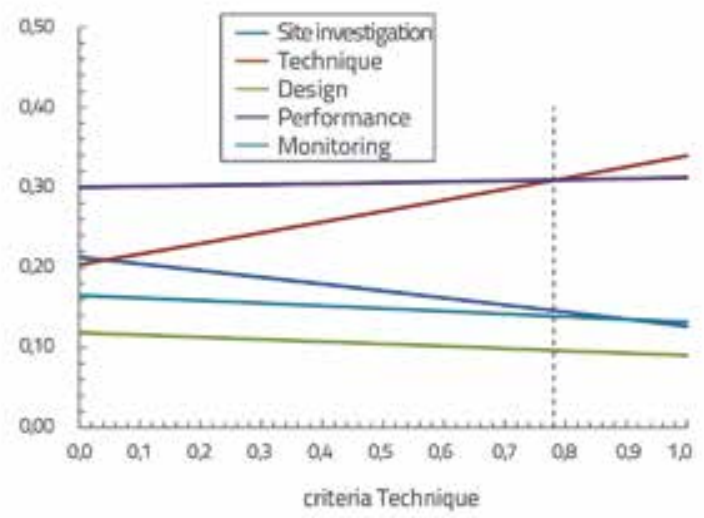

Figure 11. Sensitivity analysis of changes to Technique risk with respect to Performance risk
Figure 12 shows Risk exposure as a normalized multiple of priority vector of Risk Probability shown in Table 1, and Risk Impact obtained by ANP model 2 shown on Figure 10. The results of the ANP model with outer and inner dependence show that a change in order on the risk ranking list has occurred and that most of the resources should be directed towards managing the risks Performance (30.4\%), followed by Site investigation (28.7\%), Technique (26.3\%), Design (7.2\%) and Monitoring (7.4\%)

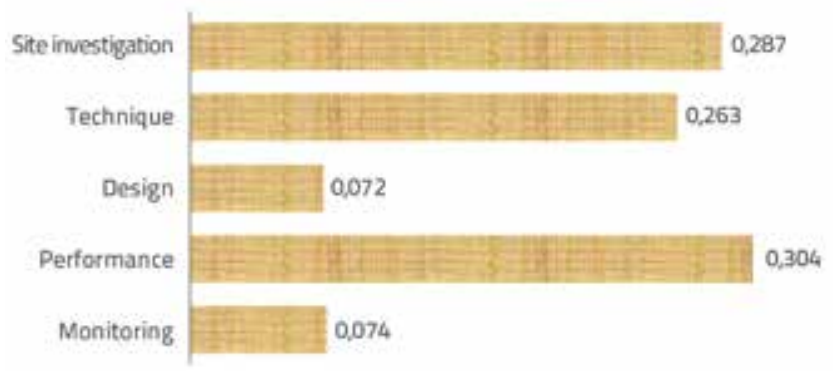

Figure 12. Risk Exposure for the ANP model 2 with outer and inner dependence

\section{Discussions}

In the modern construction industry, demands are increasingly made to place foundations of a heavy building on the ground with poor load-bearing and stiffness characteristics. Making decisions on building foundations in such circumstances depends on the system used to study a whole series of influencing factors, the adequacy and quality of information, the number of alternatives from which a selection is to be made, and the use of appropriate models and techniques in selecting optimum and most favourable alternatives. One of possible solutions is ground improvement. Mechanical characteristics of ground can be improved using various engineering procedures, including compaction and mixing existing ground with various forms of binding compounds. In this way, the natural ground composition is converted into a new material with a quality that guarantees proper safety to the future facility.

The cement and limestone are currently most often used as binding compounds in the ground mixing process. However, they consumes large quantities of natural raw materials and fossil fuels, and consequently release huge quantities of $\mathrm{CO}_{2}$ into the atmosphere. Any reduction in the use of cement and limestone would also reduce $\mathrm{CO}_{2}$ emissions and result in a sustainable ground improvement. This can be achieved by introducing synthetic binding compounds, so called geopolymers, which utilise waste materials from other industrial processes such as slag and fly ash. Quantifying the degree of success of undertaken works and manage risks is possible by selecting ecologically-friendly synthetic binding compounds, appropriate foundations, and a proper quality control.

Risks appear in all phases of construction projects, and hence also in foundation construction projects where sustainable 
ground improvement is applied. Risk assessment is carried out for each identified risk throughout the life cycle of the project. Risk management in nature is a cyclic process. Risks should be identified prior to start of the project, or before commencement of certain phases of the project. The circumstances surrounding the project also generate new sources of risk during the project. Such new risks should be analysed together with earlier identified and analysed risks in a continuous attempt to assess the probability of occurrence and damaging action of newly-occurring risks with respect to existing ones. This creates the need to manage risks continuously, i.e.in all phases of the project.

The risk is assessed by determining risk exposure. Risk exposure represents a multiple of risk probability and risk impact. Determining risk exposure for all identified risks, and placing risks in a mutual relationship, results in creation of the risk priority list. Depending on the risk ranking on the risk priority list, appropriate resources are implemented to form a planned risk response. The risk priority list resulting from risk assessment may be determined by quantitative or qualitative analyses. A quantitative analysis requires the use of an appropriate database containing data from previously undertaken projects and allowing direct calculation of risk exposure. Since this is most often impossible in real life situations, a qualitative analysis is also applied as it provides more or less consistent assertions, which are used to determine risk exposure levels.

The risk assessment was conducted by means of the hierarchical AHP model, the network ANP model 1 with outer dependence, and the network ANP model 2 with outer and inner dependence. The result of risk assessment is the risk exposure level which is, for each key risk, a multiple of the risk probability and risk impact. Risk probabilities for each risk are independent variables and, in all three models, they possess a hierarchical structure providing the same results. The advantages of the ANP model are evident in the changes of risk impact values in all three models. The risk impact obtained for all three models is shown in Figure 11.

Figure13 shows the risk impact obtained for all three models.

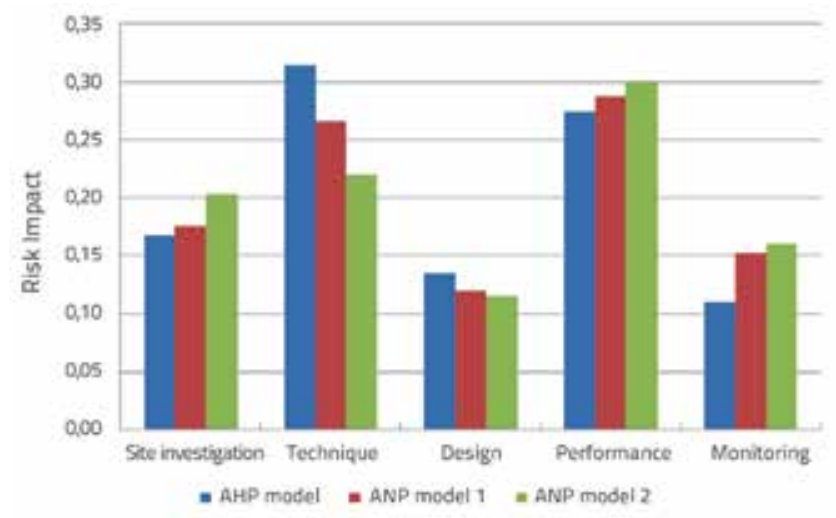

Figure 13. Risk impact for all three analysed models
The AHP model showed that the sustainable ground improvement is mostly hindered by an inappropriate selection of ground improvement technology, and inadequate realization of construction works relating to ground improvement. As expected, the greatest impact due to hierarchical structure was generated by selection of an inappropriate ground improvement technology, since it has the greatest impact with respect to the Environment criterion and, furthermore, the Environment criterion has the greatest significance for Impact.

The ANP model 1 with outer dependence expanded the scope of the AHP model by introducing mutually interacting influences of criteria and alternatives on the sustainable ground improvement. A dominant role is still reserved to the selection of an inappropriate ground improvement technology, and inadequate realization of construction works for ground improvement. Changes occurred at the top of the risk ranking list, and so the greatest impact is attributed to construction works for ground improvement that are undertaken in an unsatisfactory manner. Here the advantages of the ANP model are clear because ground improvement works undertaken in an unsatisfactory manner are expected to significantly extend project deadlines, rather than to make an impact on the environment. This aspect is significantly less present for ground improvement works undertaken in an unsatisfactory manner. Particularly interesting are the results provided by ANP model 1 such as the impact of inadequately undertaken exploratory works, construction works undertaken in an unsatisfactory manner, and inappropriate quality control for undertaken works and, simultaneously, a reduction in the impact of inappropriately chosen technology and poor design. This could also provide an advantage by applying the network model with feedback links. All risks that increase impact occur on the terrain and involve participation of a large number of people. Therefore, a larger influence of such risks is to be expected when incorporating feedback links between risks and criteria. Reduced impacts of risks occur in the office, which usually involves participation of several persons only. Here, a reduced influence of such risks, while taking into account feedback links, is to be expected.

The ANP model 2 with outer and inner dependence has further extended the ANP model 1 by introducing mutually interacting influences of criteria on the sustainable ground improvement. The dominant role is now assumed solely by construction works undertaken in an unsatisfactory manner, while an inappropriately chosen ground improvement technology becomes almost equal to inadequately undertaken exploratory works. The results of the ANP model 2 show a further increase in the risk impact occurring on the terrain where a large number of people participate, as compared to risks that occur in offices where only a few people participate. Such results show that analytical models, combined with experience and intuition, lead to a stable-decision making process for assessing the risk related to sustainable ground improvement. 
All sensitivity analyses have exhibited an exceptional stability in the decision-making results.

\section{Conclusion}

The use of the ANP for assessing risk in sustainable ground improvement is presented using as an example a large furniture retail centre whose foundations lie on soft clay and organic soil layers. The facility is to be built directly along a river foreshore, which is why improvement of ground characteristics constitutes a significant environmental challenge due to pollution hazard. Key risks for sustainable ground improvement were identified, and they represent alternatives in the ANP model. The model comprises the main network and two subnets. The main network represents risk exposure, while the subnet represents risk probability and risk impact. The Risk Probability subnet contains only the Probability criteria and five alternatives or key risks that are analysed. The Risk Impact subnet contains four criteria: time, cost, quality and environment, and five alternatives or key risks that are analysed. The given dependences between the clusters and elements or criteria and alternatives depend on the ANP model complexity. Three models developed in this study illustrate the ANP advantages in the analysis of risks that are encountered in sustainable ground improvement. The risk assessment was carried out using the hierarchical AHP model, the network ANP model 1 with outer dependence, and the network ANP model 2 with outer and inner dependence. The AHP model has shown that the sustainable ground improvement is dominantly affected by the choice of an inappropriate ground improvement technology. This is followed by an inappropriate realization of ground improvement works. However, the ANP models have changed this order. The results of the more complex ANP models show an increase in risk impact occurring on the terrain where a large number of people are engaged, compared to risks occurring in the office where only a small number of people are engaged. The network models have resulted in a more stable decision making process, and a greater adjustment to real-life situations, with reasonable expectations. Sensitivity analyses have exhibited an exceptional stability in decisionmaking results. Possible confirmation of these trends may be obtained by using the ANP in future research on sustainable ground improvement.

\section{REFERENCES}

[1] Yee, K., Ooi, T.A.: Ground Improvement - A Green Technology towards a Sustainable Housing, Infrastructure and Utilities Developments in Malaysia, Geotechnical Engineering Journal of the SEAGS \& AGSSEA, 41, pp. 1-20, 2010.

[2] Madhyannapu, R.S., Puppala, A.J., Nazarian, S., Yuan, D.: Quality Assessment and Quality Control of Deep Soil Mixing Construction for Stabilizing Expansive Subsoils, Journal of Geotechnical \& Geoenvironmental Engineering, 136, pp. 119-129, 2010.

[3] Cerić, A., Kovačević, M.S.: Ground Improvement in Large Infrastructure Projects - Croatian Experience, Proceeding of the Second International Conference on Construction In Developing Countries, (ICCIDC-II), Kairo, pp. 615-622, 2010.

[4] McLellan, B.C., Williams, R.P, Lay, J., Riessen, A., Corder, G.D.: Costs and carbon emissions for geopolymer pastes in comparison to ordinary portland cement, Journal of Cleaner Production, 19, pp. 1080-1090, 2011

[5] Sreevidya, V., Anuradha, R., Venkatasubramani, R.: Study on Fly Ash Geopolymer Concrete to Reduce Global Warming Gases, Nature, Environment and Pollution Technology, 9, pp. 383-387, 2010.

[6] Habert, G, Lacaillerie, J.B., Roussela, N.: An environmental evaluation of geopolymer based concrete production: reviewing current research trends, Journal of Cleaner Production, 19, pp. 1229-1238, 2011.

[7] Kovačević, M.S., Simović, R., Bjegović, D., Rosković, R., Peček, N.: Soil improvement with nano waste particles, Proceedings of the International Symposium: Non-Traditional Cement \& Concrete III, Brno, pp. 362-371, 2008.

[8] Cerić, A.: Investment into New Technology under Uncertainty Conditions, Proceeding of the Fifth International Conference on Construction in the 21st Century (CITC-V), Istanbul, pp. 196-193, 2009.

[9] Tang, X., Jang, J.:Long-Term Risk Reduction of Lead-Contaminated Urban Soil by Phosphate Treatment, Environmental Engineering Science, 26, pp. 1747-1754, 2009.

[10] Marcher, T., Aydogmus, T., John, M., Fowler, M.E.: Design approach for the hybrid underground station at Union Suarel Market Street in San Francisco, Geomechanics and Tunnelling, 2, pp. 387-399, 2009

[11] Fuchsman, P., Lyndall, J., Bock, M., Lauren, D., Barber, T., Leigh, K., Perruchon, E., Capdevielle, M.: Terrestrial ecological risk evaluation for triclosan in land-applied biosolids, Integrated Environmental Assessment and Management, 6, pp. 405-418, 2010.

[12] Kirman, C., Budinsky, R.A., Yost, L., Baker, B.F., Zabik, J.M, Rowlands, J.C., Long, T.F., Simon, T.: Derivation of Soil CleanUp Levels for 2,3,7,8-Tetrachloro-dibenzo-p-dioxin (TCDD) Toxicity Equivalence $\left(T E Q_{D / F}\right)$ in Soil Through Deterministic and Probabilistic Risk Assessment of Exposure and Toxicity, Human and Ecological Risk Assessment, 17, pp. 125-128, 2011.

[13] Tang, Z.Q., Wu, H.M., Bian, Y.W.: A Case Library Creating Method Based on Risk Control of Tunnel Engineering, Advanced Materials Research, 323, pp. 151-156, 2011.

[14] Dikmen, I., Birgonul, M.T., Ozorhon, B.: Project Appraisal and selection using the Analytical Network Process, Canadian Journal of Civil Engineering, 34, pp. 786-792, 2007. 
[15] Cerić, A., Marić, T.: Određivanje prvenstva pri upravljanju rizicima građevinskih projekata, GRADEVINAR 63 (2011) 3, pp. 265-271.

[16] Cioffi, D.F., Khamooshi, H.: A practical method of determining project risk contingency budgets, Journal of the Operational Research Society, 60, pp. $565-571,2009$.

[17] Zavadaskas, E.K., Turskis, Z., Tamošaitiene, J.: Risk Assessment of Construction Projects, Journal of Civil Engineering and Management, 16, pp. 33-46, 2010.

[18] Seifert, I., Thieken, A.H., Merz, M., Borst, D., Werner, U.: Estimation of industrial and commercial asset values for hazard risk assessment, Natural Hazards, 52, pp. 453-479, 2010.

[19] Karimi Azari, A.R., Mousavi, N., Mousavi, S.F., Hosseini, S.B.: Risk assessment model selection in construction industry, Expert Systems with Applications, 38, pp. 9105-9111, 2011.

[20] Li, J., Zou, P.X.W.: A Fuzzy AHP Based Risk Assessment Methodology for PPP Projects, Journal of Construction Engineering and Management, 137, pp. 1205-1209, 2011.

[21] Jaafari, A.: Management of Risks, Uncertainties, and Opportunities on Projects: Time for a Fundamental Shift, International Journal of Project Management, 19, pp. 89-101, 2001

[22] Taroun, A., Yang, J.B., Lowe, D.: Construction Risk Modelling and Assessment: Insights from a Literature Review, The Built \& Human Environment Review, 1, pp. 87-97, 2011.

[23] Cerić, A., Marčić, D., Ivandić, K.: A Risk Assessment Methodology in Tunneling, Technical Gazette, 18, pp. 526-536, 2011.

[24] Project Management Institute (PMI): A Guide to the Project Management Body of Knowledge (PMBOK@ Guide), Third Edition Project Management Institute Publishing Division, 2004.

[25] Fu, G., Butler, D., Khu, S.T.: Multiple objective optimal control of integrated urban wastewater systems, Environmental Modelling \& Software, 23, pp. 225-234, 2008.

[26] Levner, E., Ganoulis, J., Alcaide López de Pablo, D., Linkov, I.: Sustainable Management of Water Resources and Minimization of Environmental Risks A Multi-Portfolio Optimization Model, Earth and Environmental Science, 3, pp. 329-348, 2010.

[27] Argent, R.M., Perraud, J.M., Rahman, J.M, Grayson, R.B. Podger, G.M.: A new approach to water quality modelling and environmental decision support systems, Environmental Modelling \& Software, 24, pp. 809-818, 2009.

[28] Linkov, I., Loney, D., Cormier, S., Satterstrom, S.F., Bridges, T. Weight-of-evidence evaluation in environmental assessment Review of qualitative and quantitative approaches, Science of The Total Environment, 407, pp. 5199-5205, 2009.

[29] Chen, Z., Zhao, L., Lee, K.: Environmental risk assessment of offshore produced water discharges using a hybrid fuzzystochastic modeling approach, Environmental Modelling \& Software, 25, pp. 782-792, 2010.

[30] Saaty, T.L.: Fundamentals of the analytic network process: dependence and feedback in decision-making with a single network, Journal of Systems Science and Systems Engineering, 13, pp. 129-157, 2004.

[31] Saaty, T.L.: Theory and Applications of the Analytic Network Process. RWS Publications, Pittsburgh, 2005.

[32] Saaty, T.L.: Rank from comparisons and from ratings in the analytic hierarchy/network processes, European Journal of Operational Research, 168, pp. 557-570, 2006.
[33] Saaty, T.L.: Time dependent decision - making; dynamic priorities in the AHP/ANP: Generalizing from points to functions and from real to complex variables, Mathematical and Computer Modelling, 7-8, pp. 860-891. 2007

[34] Saaty, T.L.: The analytic network process, Iranian Journal of Operations Research, 1, pp. 1-27, 2008.

[35] Wolfslehner, B., Vacik, H.: Evaluating sustainable forest management strategies with the analytic network process in a pressure-state-response framework, Journal of Environmental Management, 88, pp. 1-10. 2008.

[36] Tsai, W.H., Chou, W.C.: Selecting management systems for sustainable development in SMEs: A novel hybrid model based on DEMATEL, ANP, and ZOGP, Expert Systems with Applications, 36, pp. 1444-1458, 2009.

[37] Liu, K.F.R., Yu, C.W.: Integrating case-based and fuzzy reasoning to qualitatively predict risk in an environmental impact assessment review, Environmental Modelling \& Software, 24, pp. 1241-1251, 2009

[38] Bottero, M., Ferretti V.: Integrating the Analytic Network Process (ANP) and the Driving force-Pressure-State-Impact-Responses (DPSIR) Model for the Sustainability Assessment of Territorial Transformations, International Journal of Management of Environmental Quality, 21, pp. 618-644, 2010.

[39] Bottero, M., Comino, E., Riggio, V., 2011. Application of the Analytic Hierarchy Process and the Analytic Network Process for the assessment of different wastewater treatment systems. Environmental Modelling \& Software 26, 1211-1224.

[40] Dikmen, I., Birgonul, M.T., Ozorhon, B.: Project Appraisal and selection using the Analytical Network Process, Canadian Journal of Civil Engineering, 34, pp. 786-792, 2007.

[41] Bu-Qammaz, A.S., Dikmen, I., Birgonul, M.T.: Risk assessment of international construction projects using the analytic network process, Canadian Journal of Civil Engineering, 36, pp. 11701181, 2009.

[42] Liu, K.F.R., Lai, J.H.: Decision-support for environmental impact assessment: a hybrid approach using fuzzy logic and fuzzy analytic network process, Expert Systems with Applications, 36, pp. 5119-5136, 2009.

[43] Yiang, H., Ruan, J.: Investment Risks Assessment on High-tech Projects Based on Analytic Hierarchy Process and BP Neural Network, Journal of networks, 4, pp. 393-402, 2010.

[44] Wang, H.J., Zeng, Z.T.: A multi-objective decision-making process for reuse selection of historic buildings, Expert Systems with Applications, 37, pp. 1241-1249, 2010.

[45] Ergu, D., Kou, G., Shi, Y., Shi, Y.: Analytic network process in risk assessment and decision analysis, Computers and Operations Research, doi:10.1016/j.cor.2011.03.005, 2011.

[46] Cerić A., Katavić M.: Upravljanje održavanjem zgrada, Građevinar, 53, pp. 83-89, 2011.

[47] Marčić, D., Cerić, A. Kovačević, M.S.: Selection of a Field Testing Method for Karst Rock Mass Deformability by Multi Criteria Decision Analysis, Journal of Civil Engineering and Management, 19, pp 195-205, 2013. 